\title{
PENGEMBANGAN MODEL PEMBELAJARAN \\ USE PRE-TEST BASED LEARNING (UPBL) UNTUK MENINGKATKAN \\ KEMAMPUAN KOGNITIF PADA PELAJARAN MIKROBIOLOGI \\ KESEHATAN SISWA SMK KESEHATAN BINA KARYA MEDIKA PONOROGO
}

\author{
Ely Tri Susiani ${ }^{1}$, Isnawati ${ }^{2}$ \\ ${ }^{1}$ SMK Bina Karya Medika, Ponorogo \\ ${ }^{2}$ Universitas Negeri Surabaya, Surabaya \\ *Corresponding Address: ely@smkbkmponorogo.sch.id
}

Naskah diterima: 30Agustus 2021| Disetujui: 20 September 2021 | Diterbitkan: 22 September 2021

\begin{abstract}
The use Pre-Test Based Learning (UPBL) model is a development model of the Problem Based Learning (PBL) model that has long been used in learning. The results of the preliminary study of the implementation of Problem Based Learning (PBL) there are some students who are not complete in learning. Based on this, the researcher tried a new model, namely Use Pre-Test Based Learning (UPBL). This study aims to test the effectiveness of the Use Pre-Test Based Learning (UPBL) model to improve cognitive abilities in health microbiology lessons for health vocational students. The method in this research is Research and Development (R\&D) from Sukmadinata with 3, steps 1) preliminary study; 2) model development; and 3) model testing. The results showed that the Use PreTest Based Learning (UPBL) model was effective for improving the cognitive abilities of health vocational students in health microbiology lessons.
\end{abstract}

Keywords, Model, Learning, Use Pre-Test Based Learning (UPBL), Microbiology.

Abstrak: Model Use Pre-Test Based Learning (UPBL) merupakan model pengembangan dari model Problem Based Learning (PBL) yang sudah lama digunakan dalam pembelajaran. Hasil studi pendahuluan dilaksanakannya Problem Based Learning (PBL) ada beberapa siswa yang yang tidak tuntas dalam pembelajaran. Atas dasar hal tersebut peneliti mencoba sebuah model baru yaitu Use Pre-Test Based Learning (UPBL). Penelitian ini bertujuan untuk menguji keefektifan model Use PreTest Based Learning (UPBL) untuk meningkatkan kemampuan kognitif pada pelajaran mikrobiologi kesehatan siswa SMK kesehatan. Methode peneltian ini adalah Research and Development (R\&D) dari Sukmadinata dengan 3 langkah, 1) studi pendahuluan, 2) pengembangan model, 3) pengujian model. Hasil penelitian menunjukan bahwa model Use Pre-Test Based Learning (UPBL) efektif untuk meningkatkan kemampuan kognitif siswa SMK kesehatan pada pelajaran microbiologi kesehatan.

Kata Kunci, Model, Pembelajaram, Use Pre-Test Based Learning (UPBL), Mikrobiologi. 


\section{PENDAHULUAN}

Tujuan penelitian ini adalah untuk mengetahui tingkat keefektifan produk model pembelajaran Use Pre-Test Based Learning (UPBL). Peraturan menteri pendidikan dan kebudayaann Republik Indonesia nomor 81A tahun 2013 tentang implementasi kurikulum, lampiran IV ayat 1 menjelaskan bahwa secara prinsip kegiatan pembelajaran merupakan proses pendidikan yang memberikan kesempatan kepada peserta didik untuk mengembangkan potensi mereka menjadi kemampuan yang semakin lama semakin meningkat dalam sikap, pengetahuan, dan keterampilan yang diperlukan untuk hidup dan bermasyarakat, berbangsa, serta berkontribusi pada kesejahteraan hidup umat manusia. Kegiatan pembelajaran diarahkan untuk memberdayakan semua potensi peserta didik menjadi kompetensi yang diharapkan (Tempelaar et al., 2018). Disebutkan pula bahwa strategi pembelajaran yang akan digunakan harus diarahkan untuk memfasilitasi pencapaian kompetensi yang telah dirancang dalam dokumen kurikulum agar setiap individu mampu menjadi pebelajar mandiri sepanjang hayat dan yang pada gilirannya mereka menjadi komponen penting untuk mewujudkan masyarakat belajar.

Untuk mencapai kualitas yang telah dirancang dalam dokumen kurikulum tersebut, kegiatan pembelajaran perlu menggunakan beberapa prinsip, (1) berpusat pada peserta didik, (2) mengembangkan kreativitas peserta didik, (3) menciptakan kondisi menyenangkan dan menantang, (4) bermuatan nilai, etika, estetika, logika, dan kinestetika, dan (5) menyediakan pengalaman belajar yang beragam melalui penerapan berbagai strategi dan metode pembelajaran yang menyenangkan, kontekstual, efektif, efisien, dan bermakna (Implementasi Kurikulum 2013, 2014).

Guru harus memiliki kreatifitas untuk mengembangkan pembelajaran, baik model itu sudah mencapai tujuan atau belum (Bekker et al., 2015; Laal et al., 2014), karena inovasi akan membuat suasana proses pembelajaran siswa menjadi partisipatif. Model pembelajaran Use Pre-Test Based Learning (UPBL) merupakan model pembelajaran pengembangan dari model pembelajaran yang sudah ada yaitu Problem Based Learning (PBL). Model pembelajaran Use Pre-Test Based Learning $(U P B L)$ dilatarbelakangi oleh permasalahan peneliti sebagai guru ketika mengajar materi mikrobiologi kesehatan di SMK Bina Karya Medika Ponorogo jurusan Teknik Laboratorium Medik (TLM).

Pembelajaran di sekolah vokasi pada pembelajaran mikrobiologi merupakan pembelajaran yang didasarkan pada teori belajar kognitivisme, pembelajaran menjelaskan bagaimana faktor internal dan eksternal mempengaruhi proses individu untuk melengkapi pembelajaran. Keterlambatan dan kesulitan belajar terlihat ketika proses kognitif tidak bekerja secara teratur (Bruner, 1989). Pembelajran berfokus pada bagaimana proses mental dikaitkan dengan pengajaran. Pembelajaran 
sebelumnya dilakukan dengan model Problem Based Learning (PBL) dengan langkah-langkah, seperti 1) konsep dasar (basic consept) guru menyampaikan dasar pengetahuan dengan melakukan instruksi, sumber, koneksi dan keterampilan yang dibutuhkan dalam pembelajaran; 2) pendefinisian masalah (defining the problem), pada bagian ini guru mengutarakan skenario atau permasalahan, lalu siswa melaksanakan aktivitas brainstorming, ini berarti setiap siswa dalam grup harus menyatakan ide dan pendapat. Langkah ini bisa melahirkan berbagai macam gagasan yang tidak terduga sebelumnya; 3) pembelajaran mandiri (self learning), siswa diharuskan menemukan referensi belajar lain dari banyak sumber agar permasalahan yang ada akan semakin jelas. Referensi belajar bisa artikel, video, tempat baru, perpustakaan, berita, situs internet, buku dan apapun itu asalkan bahan berasal dari sumber yang relevan. Investigasi mengenai sumber belajar baru mempunyai misi penting. Pertama, agar siswa bisa menemukan sumber informasi dan memahami permasalahan dengan baik. Kedua, agar siswa bisa bersatu dengan satu tujuan dalam mengutarakan isu di depan kelas secara akurat dan relevan; 4) pertukaran pengetahuan (exchange knowledge) sesudah siswa memperoleh referensi yang diinginkan untuk penajaman materi. Pada sesi selanjutnya siswa diminta untuk berdiskusi dalam sebuah grup untuk mematangkan bahan sumber yang ada, lalu merumuskan solusi untuk permasalahan grup, sehingga pertukaran pengetahuan dalam grup diskusi bisa dilaksanakan dengan baik; 5) penilaian (assessment), terdapat tiga aspek penilaian yang perlu digaris bawahi, diantaranya adalah sikap, pengetahuan, dan keterampilan. Seluruh penilaian yang akan dicatat sebagai hasil akhir terdiri dari laporan, catatan, pekerjaan rumah, kuis, ujian tengah semester, dan ujian akhir semester (Duch B J, 2011).

Kelebihan model Problem Based Learning (PBL) menurut peneliti dapat membantu siswa dengan proses pemecahan masalah yang tidak rutin dengan mempertahankan ketidakpastian dan meningkatkan pemikiran kreatif, tetapi hal serupa tidak dapat dicapai untuk disposisi berpikir kritis. Oleh karena itu, studi masa depan mengenai disposisi berpikir kritis dan pendekatan Problem Based Learning (PBL) harus dilakukan pengembangan. Hal ini seiring dengan pendapat (Argaw et al., 2017) bahwa Problem Based Learning (PBL) tidak bisa merangsang siswa untuk berpikir di awal pembelajaran karena belum mendapatkan literasi maka peneliti mengembangkan dengan pre-test di langkah kedua dalam pembelajaran dengan memberikan bacaan materi pelajaran.

Mikrobiologi adalah materi yang wajib dipelajari oleh siswa SMK kesehatan jurusan teknologi laboratorium medik (TLM) (Kemenkes, 2017). Mikrobiologi adalah salah satu cabang dari disiplin ilmu biologi yang mengkaji makhluk hidup (organisme) berukuran terlalu kecil untuk dapat dilihat dengan mata telanjang. Objek kajiannya adalah semua makhluk (hidup) yang perlu dilihat dengan mikroskop, khususnya bakteri, fungi, alga mikroskopik, protozoa, dan Archaea (Wahjono, 2007). Di SMK BKM Ponorogo, virus sering dimasukkan, walaupun sebenarnya tidak sepenuhnya dapat 
dianggap sebagai makhluk hidup. Mikrobiologi setara dengan zoologi dan botani. Mikrobia mencakup berbagai macam mikrobia dan aspek-aspek biologi, di antaranya fisiologi mikrobia, ekologi mikrobia, sistematika mikrobia, dan mikrobiologi lingkungan (Padoli, 2016). Dalam dunia medis, mikrobiologi merupakan penyimpangan dari keadaan normal yang terjadi dalam struktur atau fungsi tubuh, serta timbulnya perubahan berupa adanya gejala di dalam tubuh. Jalur kompleks 2 faktor, patogen (sebagai virus) dan manusia (yang dikenai virus) akan menghasilkan penyakit flu. Sementara itu, berdasarkan jalur kompleks terdapat 3 faktor, yaitu patogen (protozoa), vektor (nyamuk), dan manusia (yang dikenai), akan menyebabkan penyakit malaria. Jika berdasarkan jalur kompleks terdapat 4 faktor, yaitu patogen (bakteri), perantara (tikus), vektor (kutu tikus), dan manusia (yang dikenai), akan mengalami penyakit tipes.

Masuknya penyakit menular ke dalam tubuh dapat terjadi dalam 3 tahapan, yaitu: 1) masuknya penyebab (mikroba) yang dapat menginfeksi tubuh melalui oral, air, bahan makanan, atau pun caracara lain; 2) pertumbuhan penyebab di dalam jaringan inang; 3) timbulnya gangguan atau pun kerusakan pada tubuh inang oleh jasad. Penyebab kerusakan tersebut menurut (Nina Marliana, 218 C.E.), yaitu 1) kerusakan secara langsung karena jaringan inang digunakan sebagai habitat pertumbuhan jasad penyebab, 2) Kerusakan secara tidak langsung karena jasad penyebab dapat menghasilkan senyawa beracun atau pun senyawa-senyawa perusak lainnya.

Model UPBL adalah model baru yang merupakan pengembangan dari model sebelumnya yang sudah ada yaitu PBL. Model pembelajaran diartikan sebagai prosedur sistematis dalam mengorganisasi pengalaman belajar untuk mencapai tujuan belajar. Ahli model (Bell, 2008) menjelaskan istilah model memiliki makna ganda, yaitu teladan, tiruan, bentuk, pola dan rancangan. Model pembelajaran adalah pola yang dipergunakan sebagai pedoman dalam perencanaan pembelajaran di kelas dan biasanya menggambarkan langkah-langkah atau prosedur yang ditempuh guru untuk menciptakan aktivitas pembelajaran yang efektif, efisien dan menarik (Supriyono, 2010: 46). Model pembelajaran merupakan kerangka berpikir yang dipakai sebagai panduan untuk melaksanakan kegiatan dalam rangka mencapai tujuan pembelajaran, atau suatu rencana mengajar yang memperlihatkan pola pembelajaran tertentu, dalam pola tersebut dapat terlihat kegiatan guru dan siswa, sumber belajar yang digunakan di dalam mewujudkan kondisi belajar atau sistem lingkungan yang memungkinkan siswa mampu belajar (Anitah, 2012). Model pembelajaran adalah kerangka konseptual yang digunakan sebagai pedoman dalam praktek pembelajaran (Suryani, 2008). Model merupakan kerangka konseptual untuk merancang dan melaksanakan pembelajaran, mengorganisasikan pengalaman belajar untuk mencapai tujuan kompetensi (Joyce, weil, 2016). 
Model merupakan pedoman dalam proses pembelajaran yang menggambarkan prosedur sistematis. Model pembelajaran memuat pendekatan, strategi, metode dan teknik. Model yang baik memiliki unsur-unsur (1) Sintaks, (2) Social system, (3) Principle of reaction, (4) Support system, dan (5) Instructional and nurturant effects. Sintakmatik adalah tahap kegiatan dalam pembelajaran, terlihat dalam RPP yang terdiri dari pendahuluan, kegiatan inti, dan penutup. Sistem sosial yang dimaksud adalah hubungan antar siswa, siswa dengan guru. Proses interaksi tersebut menerapkan konsep konstruktifisme dengan membantu siswa yang mengalami kesulitan. Prinsip reaksi ialah pola kegiatan yang menggambarkan bagaimana seharusnya guru melihat dan memperlakukan para pelajar serta cara guru memberikan respon terhadap siswa. Sistem pendukung adalah sarana, bahan, dan alat yang diperlukan untuk melaksanakan model pembelajaran. Dampak instraksional adalah hasil belajar yang dicapai siswa, dan dampak ikutan adalah hasil lainnya yang diperoleh dari suatu proses pembelajaran, sebagai akibat terciptanya suasana belajar yang dialami siswa tanpa pengarahan dari pengajar (Joyce, weil, 2016).

Model memiliki makna yang lebih luas dibanding strategi, metode dan prosedur sebagai sarana komunikasi yang penting (Arends, 1997). Model sangat dipengaruhi oleh sifat dan materi yang akan diajarkan, tujuan yang akan dicapai dan tingkat kemampuan peserta didik. Model pembelajaran yang baik adalah 1) mudah dipraktekan, 2) efektif dalam memotifasi siswa belajar, 3) efektif dalam mencapai tujuan (Uno, 2007). Model merupakan hasil kreasi orisinil dari setiap individu dalam bidang tertentu dan sangat spesifik dan berkarakteristik khusus. Setiap orang boleh dan sah membuat model berdasarkan apa yang dia mau dan mampu, tetapi hasil uji cobalah yang menentukan baik atau tidaknya model tersebut. Setiap model memiliki spesifikasi, kelemahan, dan kelebihan masing-masing dan tidak ada yang komprehensif. Model tidak boleh dikatakan lebih baik dibandingkan dengan yang lain. Model pembelajaran sangat tepat untuk materi dengan karakter tertentu, tetapi kurang cocok untuk materi dengan karakter yang lain.

Model pembelajaran dapat dikatakan baik jika berhasil dalam dua hal, yaitu proses dan produk (Samani, 2014). Model pembelajaran mampu menciptakan proses pembelajaran yang menyenangkan dan mendorong siswa untuk aktif belajar dan berfikir kreatif, maka model itu dikatakan baik (Duch B J, 2011). Apabila model pembelajaran dapat mencapai tujuan secara lebih efektif maka model itu juga dikatakan sebagai model pembelajaran yang baik (Arends \& Kilcher, 2010). Istilah yang memiliki kemiripan makna dengan istilah model antara lain 1) pendekatan pembelajaran, 2) strategi pembelajaran, 3) metode pembelajaran, 4) teknik pembelajaran, 5) taktik pembelajaran (Bruce Joyce, Marsha weil, 2016). 
Model pembelajaran Use Pre-Test Based Learning (UPBL) adalah suatu model baru dalam pembelajaran. Model pembelajaran ini pengembangan dari model yang sudah ada, yaitu Problem Based Learning (PBL). Perbedaan model Use Pre-Test Based Learning (UPBL) memiliki enam langkah. Pada langkah kedua peserta didik diberikan pre-test yang berupa pertanyaan-pertanyaan yang merujuk dari tujuan pembelajaran dan diberikan materi untuk merangsang membaca. Dengan tuntutan untuk mengerjakan test dan mengetahui jawaban maka peserta didik akan mencari jawaban untuk membaca materi yang sudah diberikan. Pertanyaan pada pre-test ini diambil dari peta konsep yang sudah dibuat oleh guru. Literasi pada awal pembelajaran ini sangat berpengaruh pada keaktifan dan konsentrasi siswa pada pendalaman materi pelajaran (Muhammad Adri, 2010). Langkah-langkah pembelajaran Use Pre-Test Based Learning (UPBL) dapat dilihat pada bagan berikut.

Tabel 1. Langkah-langkah pembelajaran UPBL

\begin{tabular}{cl}
\hline \multicolumn{2}{c}{ Model Pembelajaran Use Pre-Test Based Learning } \\
\hline TAHAP & Mengorientasikan peserta didik terhadap masalah \\
TAHAP & Pre-test dengan memberikan bacaan \\
TAHAP & Mengorganisi peserta didik untuk belajar \\
TAHAP & Membimbing penyelidikan individu/kelompok \\
TAHAP & Mengembangkan dan menyajikan hasil karya \\
TAHAP & Menganalisis dan mengevaluasi proses \\
\hline
\end{tabular}

\section{METODE}

Penelitian ini merupakan penelitian pengembangan dengan 3 langkah, 1) studi pendahuluan, 2) pengembangan model, 3) pengujian model (Sukmadinata, 2007). Pada studi pendahuluan peneliti sebagai guru mendapatkan nilai yang tidak maksimal pada materi microbiologi dengan pembelajaran model Problem Based Learning (PBL). Hal ini bisa dilihat dari nilai ujian siswa $60 \%$ tidak memenuhi kriteria ketuntasan minimal (KKM). Pada tahap penembangan model peneliti mengembangkan dengan menambahkan satu tahap yaitu tahap ke-2 pada model Problem Based Learning (PBL) dengan memberikan pre-test untuk merangsang kemauan siswa dalam literasi, sehingga pada tahap pembelajaran selanjutnya sudah memahami tentang mocrobiologi. Pengujian model dalam penelitian ini menggunakan teori (Budiyono, 2016), dilakukan terhadap kelas eksperimen dan kelas kontrol. Pada kelas eksperimen pembelajaran diterapkan model Use Pre-Test Based Learning (UPBL) dan pada kelas control diterapkan model Problem Based Learning (PBL). Analisis uji dilakukan dengan uji deskriptif statistik, uji normalitas, uji homogenitas dan uji paired sample t-test (Siswandari, 2017). 


\section{HASIL DAN PEMBAHASAN}

Analisis deskriptif dilakukan untuk memaparkan dan menggambarkan data penelitian mencakup jumlah data, nilai minimum, nilai maximum, nilai rata-rata dan lain sebagainya.

Tabel 2. Hasil uji deskriptif statistik produk model use Pre-Test Based Learning (UPBL) pada mata pelajaran mokrobiologi di SMK Bina Karya Medika Ponorogo

\begin{tabular}{lccccr}
\hline N & & Minimum & Maximum & Mean & Std. Deviation \\
\hline Pre-test Eksperimen & 22 & 56 & 77 & 67.77 & 6.332 \\
Post-test Eksperimen & 22 & 55 & 92 & 84.14 & 7.428 \\
Pre-test Kontrol & 20 & 52 & 81 & 66.50 & 7.997 \\
Post-test kontrol & 20 & 67 & 89 & 77.65 & 5.815 \\
Valid N (listwise) & 20 & & & &
\end{tabular}

Interpretasi uji deskriptive statistik, pre-test dan post-test di kelompok eksperimen diketahui bahwa pada data pre-test skor minimum Pre-test Eksperimen adalah 56 dan maximum 77. Langkah berikutnya dilakukan pembelajaran Use Pre-Test Based Learning (UPBL), dan dilakukan post-test maka skor minimum adalah 55 dan maximum 92 dan rata-rata juga naik dari 67,77 menjadi 84,14.

Hasil uji normalitas di kelompok eksperimen dilakukan dengan SPSS diperoleh hasil sebagai berikut.

Tabel 3. Hasil uji normalitas produk model use Pre-Test Based Learning (UPBL) pada mata pelajaran mokrobiologi di SMK Bina Karya Medika Ponorogo

\begin{tabular}{|c|c|c|c|c|c|c|c|}
\hline & \multirow[b]{2}{*}{ Kelas } & \multicolumn{3}{|c|}{ Kolmogorov-Smirnov ${ }^{a}$} & \multicolumn{3}{|c|}{ Shapiro-Wilk } \\
\hline & & Statistic & df & Sig. & Statistic & df & Sig. \\
\hline \multirow[t]{4}{*}{ Hasil belajar siswa } & Pre-test Eksperimen & .133 & 22 & $.200^{*}$ & .945 & 22 & .250 \\
\hline & Post-test Eksperimen & .243 & 22 & .002 & .685 & 22 & .000 \\
\hline & Pre-test Kontrol & .175 & 20 & .110 & .948 & 20 & .342 \\
\hline & Post-test Kontrol & .158 & 20 & $.200^{*}$ & .948 & 20 & .338 \\
\hline
\end{tabular}

Berdasarkan output diketahui nilai signifikansi (Sig) untuk semua data baik pada uji Kolmogorov-Smirnov maupun uji Shapiro-Wilk > 0,05, Maka dapat disimpulkan bahwa data penelitian berdistribusi NORMAL. 
Hasil uji homogenitas di kelompok eksperimen dilakukan dengan SPSS diperoleh hasil sebagai berikut.

Tabel 4. Hasil uji homogenitas produk model use Pre-Test Based Learning (UPBL) pada mata pelajaran mokrobiologi di SMK Bina Karya Medika Ponorogo

\begin{tabular}{|c|c|c|c|c|c|}
\hline & & Levene Statistic & df1 & df2 & Sig. \\
\hline \multirow[t]{8}{*}{ Hasil belajar siswa } & Based on Mean & 1.003 & 3 & 80 & .396 \\
\hline & Based on Median & .778 & 3 & 80 & .509 \\
\hline & Based on Median and & & & & \\
\hline & & .778 & 3 & 68.800 & .510 \\
\hline & with adjusted df & & & & \\
\hline & Based on trimmed & & & & \\
\hline & & 1.053 & 3 & 80 & .374 \\
\hline & mean & & & & \\
\hline
\end{tabular}

Berdasarkan output diketahui nilai signifikansi (Sig) based on mean adalah sebesar, $396>0,05$ sehingga dapat disimpulkan bahwa varians data post-test kelas eksperimen adalah sama atau HOMOGEN. Hasil uji Paired Sample T Test, setelah dilakukan uji normalitas dan uji homogenitas pada kelompok eksperimen. Uji ini dilakukan untuk mengetahui apakah ada pengaruh sebelum dilakukan uji pembelajaran produk use Pre-Test Based Learning (UPBL) atau tidak. Uji Paired Sample T Test ini dilakukan dengan dengan SPSS diperoleh hasil sebagai berikut.

Tabel 5. Hasil uji paired sample t-test produk model use Pre-Test Based Learning (UPBL) pada mata pelajaran mokrobiologi di SMK Bina Karya Medika Ponorogo

\begin{tabular}{|c|c|c|c|c|c|c|c|c|c|}
\hline \multicolumn{10}{|c|}{ Paired Differences } \\
\hline & & & & & \multicolumn{2}{|c|}{ 95\% Confidence } & & & \\
\hline & & & & & \multicolumn{2}{|c|}{ Interval of the } & & & \\
\hline & & & \multirow[b]{2}{*}{ Std. } & \multirow[b]{2}{*}{ Std. Error } & \multicolumn{2}{|c|}{ Difference } & & & \multirow[b]{2}{*}{ Sig. (2- } \\
\hline & & & & & & & & & \\
\hline & & Mean & Deviation & Mean & Lower & Upper & $\mathrm{t}$ & $\mathrm{df}$ & tailed) \\
\hline \multirow[t]{4}{*}{ Pair 1} & Pre-test & & & & & & & & \\
\hline & Eksperimen - & \multirow[b]{2}{*}{-16.364} & \multirow[b]{2}{*}{11.240} & \multirow[b]{2}{*}{2.396} & \multirow[b]{2}{*}{-21.347} & \multirow[b]{2}{*}{-11.380} & - & \multirow[b]{2}{*}{21} & \multirow[b]{2}{*}{.000} \\
\hline & Post-test & & & & & & 6.828 & & \\
\hline & Eksperimen & & & & & & & & \\
\hline \multirow[t]{3}{*}{ Pair 2} & Pre-test & & & & & & & & \\
\hline & Kontrol - & & \multirow[b]{2}{*}{6.659} & \multirow[b]{2}{*}{1.489} & \multirow[b]{2}{*}{-14.267} & \multirow[b]{2}{*}{-8.033} & & \multirow[b]{2}{*}{19} & \multirow[b]{2}{*}{.000} \\
\hline & Post-test kontrol & -11.150 & & & & & 7.488 & & \\
\hline
\end{tabular}


Berdasarkan output paired sample t-test diperoleh nilai signifikansi (2-tailed) sebesar 0,000 < 0,05 maka dapat disimpulkan ada perbedaan rata-rata hasil belajar siswa untuk pre-test kelas eksperimen dengan post-test kelas eksperimen model Use Pre-Test Based Learning (UPBL). Perbedaan rata-rata juga sangat signifikan antara kelas eksperimen dengan kelas kontrol pada materi mikribiologi di SMK Kesehatan Bina Karya Medika Ponorogo. Hasil uji keefektifan ini menolak dari konsep yang sudah di sampaikan oleh (Peraturan Menteri Pendidikan dan Kebudayaan Republik Indonesia Nomor 22 Tahun 2016 Tentang Standar Proses Pendidikan Dasar dan Menengah, 2016) untuk melakukan model apa yang disebut Problem Based Learning (PBL), dan terbukti dalam uji pengembangan model Use Pre-Test Based Learning (UPBL) lebih baik

\section{KESIMPULAN}

Berdasarkan analisis statistis spps terhadap uji paired sample t-test maka dapat disimpulkan bahwa ada perbedaan rata-rata hasil belajar siswa untuk pre-test kelas eksperimen dengan post-test kelas eksperimen model Use Pre-Test Based Learning (UPBL). Perbedaan rata-rata juga sangat signifikan antara kelas eksperimen dengan kelas kontrol pada materi mikribiologi di SMK Kesehatan Bina Karya Medika Ponorogo sehingga dapat disimpulkan bahwa produk model Use Pre-Test Based Learning (UPBL) yang merupakan pengembangan dari model Problem Based Learning (PBL) efektif.

\section{DAFTAR PUSTAKA}

Arends, R. I., \& Kilcher, A. (2010). Teaching for student learning: Becoming an accomplished teacher. In Teaching for Student Learning: Becoming an Accomplished Teacher. https://doi.org/10.4324/9780203866771

Bruce Joyce, Marsha weil, E. calhoun. (2016). Models of teaching (P. Rehanjanda (ed.)). pustaka karya.

Budiyono. (2016). Statistika untuk penelitian. UNS Press.

Duch B J. (2011). The Power of Problem-Based Learning: a practical "how to" for teaching undergraduate courses in any discipline. Higher Education Research and Development, 30(3), 329-341. https://doi.org/10.1080/07294360.2010.501074

Peraturan Menteri Pendidikan dan Kebudayaan Republik Indonesia Nomor 22 Tahun 2016 tentang Standar Proses Pendidikan Dasar dan Menengah, 53 Journal of Chemical Information and Modeling 1689 (2016). 
Muchlas Samani. (2014). Konsep dan model pendidikan karakter. Rosda karya. Muhammad Adri. (2010). Learning Management System. Education And Training,June.

Nana Syaodih Sukmadinata. (2007). Metode penelitian pendidikan. Rosda karya.

Nina Marliana, R. M. (218 C.E.). Imunoserologi (p. 326). Kemekes RI.

Padoli. (2016). Mikrobiologi dan parasitologi keperawatan (p. 295). Kemekes RI. Randy L Bell. (2008). Teaching the nature of science through process skill-activities for grades. Pearson Education, Inc.

Siswandari. (2017). Statistika Computer Based. UNS Press.

Suryani, N. (2008). Implementasi Model Pembelajaran Kolaboratif untuk Meningkatkan Ketrampilan Sosial Siswa. Journal of Social Sciences, 2, 1-23.

Tempelaar, D., Rienties, B., Mittelmeier, J., \& Nguyen, Q. (2018). Student profiling in a dispositional learning analytics application using formative assessment. Computers in Human Behavior, 78, 408-420. https://doi.org/10.1016/j.chb.2017.08.010

Wahjono, H. (2007). Peran Mikrobiologi Klinik Pada Penanganan Penyakit Infeksi.

Badan Penerbit Universitas Diponegoro Semarang, 24.

Widodo Supriyono. (2010). Cooperative learning theory dan aplikasi paikem. Pustaka Pelajar. 